ISSN 2519-2523 (print) Chornomors'ka mynuvshyna. -2019. - No.14.

DOI: $10.18524 / 2519-2523.2019 .14 .187112$

УДК 94(71=161.2)

\title{
ACTIVITIES OF THE UKRAINIAN MUSEUM OF CANADA TO PRESERVE THE NATIONAL HERITAGE (second quarter of 20th - beginning of 21st century)
}

\author{
Anatoliy Bodrug \\ ORCID: https://orcid.org/0000-0001-6718-4957 \\ Post-graduate student \\ of the Department of History of Ukraine \\ Odessa I. I. Mechnikov National University \\ 2, Dvoryanska Str., Odessa, 65082, Ukraine \\ metall.feniks@yandex.ua
}

The purpose of this research is to review the activities of the Ukrainian Museum of Canada and substantiate its contribution to the process of preserving the cultural heritage of the Ukrainian diaspora. Thanks to the memorial protection activity of the museum under study, not only the sprouts of Ukrainian culture were preserved, but also multiplied, despite the era of military violence and in the situation of practical isolation from ethnic territory. To achieve this goal, the necessary number of sources and historiographic literature was attracted, which dealt with various aspects of the problem. The author applied the following general historical scientific research methods as historical-genetic, historical-comparative, and historical-typological. Within the framework of this scientific article, the genesis of the museum institution was examined, the existing collections were typologized, and their value was analyzed. Special attention is devoted to the study of the role of founders and patrons in the development of the Ukrainian Museum of Canada. For the first time an attempt has been made to generalize various aspects of the problem.

Keywords: Ukrainian diaspora of Canada, Ukrainian Museum of Canada, Ukrainian art, Ukrainian Women's Association of Canada, museology.

Анатолій Бодруг

ORCID: https://orcid.org/0000-0001-6718-4957

Аспірант кафедри історії України,

Одеський національний університет імені I. I. Мечникова

Вум. Дворянська, 2, Одеса, 65082, Україна

metall.feniks@yandex.ua

\section{ДІЯАЬНІСТЬ УКРАЇНСЬКОГО МУЗЕЮ КАНАДИ ЗІ ЗБЕРЕЖЕННЯ НАЦІОНААЬНОЇ СПАДЩИНИ (дрУга чверть XX - Початок XXI ст.)}

Мета даного наукового дослідження полягае у розгляді діяльності Украӥнсъкого музею Канади та обтрунтуванні його внеску у проиес збереження культурної спадиини украӥнської діаспори. Завдяки пам'яткоохоронній діяльності досліджуваного музею було не тільки збережено, а $і$ примножено паростки української культури, незважаючи на добу воєнного лихоліття та у становищі практичної відірваності від етнічної території. Для досягнення зазначеної мети було залучено необхідну кількість джерел та історіографічної літератури, які торкались різних аспектів порушеної проблеми. 
Автором було застосовано такі загальноісторичні наукові методи дослідження, як історико-генетичний, історико-порівняльний та історикотипологічний. У межах даної наукової статті було розглянуто генезис музейної установи, типологізовано наявні колекиії та проаналізовано їх иінність. Окрему увагу присвячено дослідженню ролі засновників та меценатів у розвитку Українського музею Канади. Вперше здійснена спроба узагальнення різних аспектів проблеми.

Ключові слова: украӥнська діаспора Канади, Український музей Канади, украӥнсъке мистеитво, Украйнсъка асоиіаиія жінок Канади, музеєзнавство.

«Кумьтура й свідомість виростає з минулого, а музеї то неначе оаза старовини серед сучасності. Тут зберігаються пам'ятки славного минулого, свідоцтва буйного життя. I кожний, навіть дрібний предмет уміє тут розказати тому, хто хоче скухати, свою історію..." [6, с. 379] відзначав видатний український педагог, музеєзнавець, мітературознавець та громадський діяч Євген-Юлій Пеменський. I дійсно, життя кожного народу від початку його історичного буття овіяно мегендами

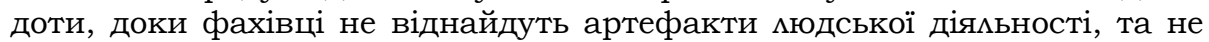
з'ясують їх національно-культурну цінність. Проте не менш важливою справою є збереження історичних пам'яток у їх первісному вигляді 3 метою передачі у спадок майбутнім покомінням. Вже у добу Київської Русі було прийнято зберігати офіційні документи, дорогоцінні книги, золоті та срібні витвори мистецтва у храмах, які у епоху Середньовіччя були важливими освітніми та культурними центрами. 3 ростом національної свідомості та наукового зацікавлення до історичного минулого різних народів в ХІХ ст. у світі відбувався бурхливий розвиток музейних установ, діяльність яких була направлена не мише на охорону та показ пам'яток кумьтури, але i на їх наукове обгрунтування. Аналогічні процеси відбувались і на території України, яка в той час переживала становище бездержавності у складі Австро-Угорської та Російської імперій. Тому український народ відчував потребу у збереженні національної ідентичності, яка простягалась у вимірі охорони існуючих та примноженні нових культурних надбань. Коли у пошуках кращої домі у кінці XIX ст. українці досягли берегів Канадського домініону, то подібні труднощі спіткали наш народ і на чужині. Проте вже під час другої хвимі еміграції (1920-1941рр.) відбулась певна консоцідація українців у діаспору та розпочалось заснування спілок, головною метою яких стало збереження національної самобутності. Подібним утворенням стала Українська асоціація жінок Канади (Ukrainian Women's Association of Canada (UWAC), яка була заснована у 1926 р. в м. Саскатун (провінція Саскачеван). Саме ця організація виступила засновником Українського музею Канади - історично, першої музейної установи української громади на території цієї держави.

Актуальність даного дослідження пов'язана з сучасним розвитком української культури, з відродженням національних традицій не тільки у етнічних межах, a i закордоном, зокрема у Канаді. До того ж, 
збереження кумьтурних пам'яток у наш час $\epsilon$ не менш актуамьною справою дмя України.

Окремі аспекти даної проблеми були розкриті в працях таких дослідників, як: Драган Р. [3], Стечишин С. Т. [8], Ноконі В. А. [12]; [13], Остризнюк Н. [14] та Ткачук М. [15]. Проте, на наш погляд, діяльність та розвиток Українського музею Канади варта більш глибокого наукового дослідження. Безперечно, важливою справою є розгляд фондів музею, їх ціннісний аналіз, а також діяльність громадських діячів, музейних працівників, членів Української асоціації жінок Канади, які доклали неабиякі зусимля у збирання колекцій та відкриття музейної установи.

До початку другої хвимі еміграції українці, які проживами в Канаді вже понад 30 років, встигли отримати репутацію вправних господарів, наполегливих освоювачів цілинних земель. Проте ще на початку свого проведення аграрна помітика Канади мала на меті мише економічне та геополітичне забарвлення. Тому нові переселенці не вважались повноправними членами суспільства, а радше запрошеними працівниками дмя освоєння дикого степу та притримання військової експансії з боку США. Пізніше становище українського народу ще більше погіршилось, коли в період Першої світової війни їх визнали шпигунами з АвстроУгорщини - ворогуючої сторони, бо переважна більшість українців якраз була вихідцями з територій, які належали цій країні. Отже, для розвитку національної культури не було і мови, хоча існувала реальна загроза асиміляції. Ситуація дещо поміпшилась, коми уряд Канади прийняв ціку низку законодавчих актів (зокрема зміни у Канадському імміграційному акті за 1923 р.), заохочуючих імміграцію та спрямованих на покращення соціального забезпечення, що мало на меті підвищення політичної популярності, пришвидшення економічного росту після воєнного михоліття та уповільнення сепаратизму 3 боку населення східних провінцій. Тим часом у Помьщі та СРСР розпочинається репресивна політика, спрямована проти колишніх мідерів УНР та активних борців за незалежність нашої держави, так розпочалася друга хвиля української еміграції (1920-1941 рр.). До Канади, окрім трудових емігрантів, потрапмяє українське духівництво, культурні та громадські діячі, які згуртовують українців довкола національно-культурної ідеї, засновують спілки, будують церкви, відкривають нові школи, інститути, музеї. Тобто нові переселенці зробими внески у збереження та примноження всього українського, а також познайомили з духовним багатством різнобарвне населення Канади.

Зростання Українського музею Канади переплітається 3 розвитком Української асоціації жінок Канади, бо історія музею розпочинається саме із зародку ідеї в рамках даної спілки [6, с. 392]. 3 самого початку свого функціонування представниці Української асоціації жінок Канади чітко окреслили власну мету, яка полягала в популяризації національної культури, тобто розширенні знань про стилі та справжність українського мистецтва дмя канадської спільноти через функції збору, освіти та інтерпретації багатих скарбів української культури [15, с. 974]. Тому ще в 1929 р. за сприяння голови Української асоціації жінок Канади - 
Савемли Стечишин та виконавчих членів - Ненсі Рурик, Дарії Янди і Рози Драган в університеті Саскачевану в м. Саскатун було проведено першу виставку з демонстрацією "писанок" та предметів ремісництва. Проте дана виставка поки що мала не регулярний характер та була своєрідною "пробою пера". 31930 по 1936 рр. чценами асоціації було підготовлено та проведено цілу низку виставок в різних містах Канади: Саскатуні, Едмонтоні, Торонто, Реджайні та Вінніпезі. Ці виставки носили переважно декоративно-прикладний характер та мали на меті познайомити канадійців 3 культурою Західної України. 3 ростом чисельності артефактів та жвавого інтересу, як з боку діаспори, так і 3 боку провінційного уряду, постала проблема зберігання та експонування нових колекцій. 17 серпня 1936 р. в м. Саскатун відбулось зібрання Української асоціації жінок Канади, на якому було прийнято рішення про заснування "Музею українського мистецтва та культури Української асоціації жінок Канади" (з 1977 р. змінив назву на "Український музей Канади Української асоціації жінок Канади") та про початок збирання коштів на спорудження будівлі музею. Крім того, було укладено конвенцію, що окреслювала політику збору артефактів, які стануть частиною постійної комекції майбутнього музею. В 1937 р. було придбано колекцію, зібрану активісткою Ганною Романчич, що налічувала близько 200 предметів, які охоплювали зразки ранньої народної та церковної вишивки, домашнього плетіння, сорочки, пояси, традиційний одяг різних регіонів та кольорову карту України 3 регіональними візерунками, виготовлену в Чехословаччині. Дані вироби було зібрано в сільських громадах Західної Канади, насамперед у провінції А^ьберта. Саме ці артефакти стали основою для постійної комекції майбутнього Українського музею Канади. Протягом 1939-1940 рр. бумо зібрано архівні матеріали, газети, книги, фотографії, усні історії та пісні, які було додано до постійної колекції. В 1940 р. на черговому зібранні Української асоціації жінок Канади було вирішено звернутися до Ради директорів Інституту П. Могили в Саскатуні за дозволом про виділення приміщення галереї дмя тимчасового розміщення експозицій музею та створено музейну фундацію для збирання пожертв, призначених на страхування та поповнення музейного фонду. Приміщення для Музею Українського Народного Мистецтва знайдено при Інституті П. Могили в Саскатуні тому, що ця інституція найбільше доступна загалові і $€$ осередком нашої культури в Канаді [3, с. 148]. На думку канадійської дослідниці Наталі Остризнюк колекції асоціації настільки вразили студентів, що у будь-якому випадку Могилянці почали збирати вироби ручної роботи, такі як вишивка та писанки [14, с. 95]. Крім того, співробітники та вихованці інституту допомагали чменам асоціації у придбанні та облаштуванні обладнання дмя демонстрації та підготовки артефактів до виставок, що можна розцінювати, як вагомий внесок, бо засновники музею мали досить обмежений бюджет. Нарешті 27 грудня 1941 р. під час 15-го ювілейного зібрання Української асоціації жінок Канади у будівлі Інституту П. Могили відбулась церемонія відкриття першої галереї музею. На урочистому зібранні були присутніми 
представники асоціації: президент М. Ткачук, виконавчі чиени Н. Рурик, М. Мадук, А. Токарек. Р. Драган, М. Буряник, регіональні представники О. Войченко (Вінніпег), Ф. Сиротюк (Едмонтон), Н. Мороз (Йорктон), К. Сакалюк (Торонто), а також відомі громадські діячі та уряд провінції Саскачеван. Марія Ткачук (президент асоціації в 1939-1942 рр.) вважала, що це зібрання стало надзвичайною подією в історії української діаспори Канади - офіційним відкриттям першого українського музею в Канаді та на північноамериканському континенті, Музею Української асоціації жінок Канади [15, с. 980]. 3 відкриттям галереї в діяльності музею посилились науково-практична та освітня складові.

В роки воєнного михоліття працівники музею здійснювали благодійну діяльність, демонструючи вироби з військовою вишивкою, кошти від якої йшли на реабілітаційні та освітні потреби. В 1944 р. асоціацією було високо оцінено роботу на цьому поприщі - Р. Драган та М. Бурявк, які відповідно очолили відділ народних ремесел та музейний комітет.

Ріст зацікавлення до української культури в Канаді та розширення регіональних представництв Української асоціації жінок Канади призвели до створення провінційних філій-музею. До того ж, через значні відстані не вдавалось вчасно виконувати програмні плани у Саскатуні. Потрібно бумо децентралізувати заплановану роботу. Тому в 1944 р. асоціацією було прийнято рішення про створення музейних фікій в Торонто та Едмонтоні. Подібні філії було відкрито в 1950 р. у Вінніпезі та в 1956 р. у Ванкувері.

Завдяки зверненням та особистим контактам Н. Когуської, яка обіймала посаду президента Української асоціації жінок Канади 3 1946 р. було зібрано велику кількість цінних артефактів. 3 дозволу виконавчої ради Інституту П. Могили у 1948 р. музей отримав в розпорядження більше галерейного простору. Таким чином, було відкрито нову експозицію, яка відображала не мише історію першої імміграції українців до Канади, але й історію міжвоєнної та післявоєнної імміграції. Досить цікавим експонатом даної експозиції стала мініатюрна модемь української хати придбана ще в 1945 р., яка була розроблена Петром Сваричем - українським піонером та відомим громадським працівником 3 м. Вегревіля. Дана модель, була взірцем справжнього архітектурного стилю та внутрішнього оздоблення будинку українського переселенця. Іншими чудовими експонатами стали фрагменти керамічного посуду, знайденого на території України та завезеного іммігранттами до Канади. Також в цей період Українському музею Канади було подаровано зразки церковного начиння з колекції предстоятеля УГПЦ у Канаді і митрополита Вінніпегу - Іцаріона. Щоб збільшити історичну та спадкову цінність колекції, в цей період було розпочато скромне придбання малюнків та картин [15, с. 983]. 31948 по 1950 рр. діяв проект пересувної виставки, завдяки якому було познайоммено населення практично з усіх провінцій Канади з історією та культурою України. Протягом 1951-1952 рр. музейні працівники разом зі студентами Інституту ім. П. Могили здійснили проект з реставрації 
народних костюмів, виготовлених на Полтавщині та Гуцульщині. Відомо, що дані костюми використовували не тільки дмя експозицій, але і дмя проведення численних фестивалів, вистав та концертів.

Концентровані зусиляя щодо розширення комекції створили фундамент для подальших досліджень, а також розробки нових культурних проектів та виставок. Робота з культурними артефактами вимагала від працівників музею творчої наснаги, професіоналізму та особливої уваги до деталей. На думку Рози Драган: «Шоби збірка давала правдивий образ мистецтва, отже, щоби мала дійсну музейну вартість, речі мусять бути типічно (дійсно, щиро) українські, виконані народною технікою (способом), а коли прикрашені то чисто українськими взорами. Треба також, щоб кожний предмет був точно означений - треба подати місцевість, повіт (коли річ зроблена в Старім Краю) та назву організації, або особи, яка річ посилає" [3, с. 148]. Яскравим прикладом дослідницької роботи Українського музею Канади стала публікація в 1958 р. англомовного довідника "Українські вишиванки та стібки" за редакцією Ненсі Рурик. Основні розділи книги вміщували вказівки щодо виконання стібків, церковної вишивки та приклади сучасного вбрання 3 використанням вишивальних пристосувань.

Український музей Канади прагнув виконувати свою роль зберігача української спадщини, визнаючи, що український досвід має багато спільних зв'язків з іншими культурними групами [12, с. 107]. Наприкінці 1950-х - початку 1960-х рр. музей почав поширювати свою діяльність на більшу громаду Канади, розширюючи свої зовнішні зв'язки. Виникла потреба встановити контакт із подібними музейними установами. У 1954 р. було укладено угоду 3 Асоціацією музеїв Канади (Canadian Museums Association). Подібні зв'язки сприяли культурному взаємообміну, популяризації нашої культури та спільній підготовці і проведенню різних проектів.

23 грудня 1964 р. розпочався новий період в історії Українського музею Канади, саме тоді Інститут ім. П. Могили переїхав у більш сучасну будівлю, де було виділено декілька нових галерейних приміщень, що дамо змогу урізноманітнити виставки, покращити зберігання та догляд за колекціями. Станом на 1965 р. постійно діюча колекція музею налічувала вже близько 1 тис. експонатів, серед яких саме колекції текстильних виробів були найкращими, за ті які були представлені за межами України. У $1960-\mathrm{x}$ рр. було розпочато збір дуже рідкісних артефактів, які з плином часу існувала загроза втратити назавжди. Предмети, зібрані під час цього звернення, включали домашні та сільськогосподарські артефакти, книги, записи, документи, рукописи [15, с. 993]. У цей період було придбано кілька творів гончарних виробів Петра Рупчана - фермера-піонера із Буковини, який привіз із собою в Канаду гончарні секрети свого регіону, які втілив у предмети домашнього вжитку та заснував майстерню де вчив підростаюче покоління гончарному ремеслу. З 1965 по 1977 рр. головами музею Н. Буряником, С. Стратичук. О. Максим'юк та М. Ткачук було підготовмено близько 125 різноманітних виставок та культурних 
проектів. Також в музеї експонувались приватні колекції. Прикладом такої виставки було представцення у 1968 р. колекцій доктора Джорджа У. Сімпсона, відомого професора історії Університету Саскачевану та завзятого прихимьника справ української громади. 3 Українським музеєм Канади також співпрацював відомий українсько-канадський художник Василь Курилик, який в 1967 р. у приміщенні музею представив свою серію з 12 полотен "Жінки-піонери України". 31966 р. Український музей Канади бере участь у виставках та експозиціях народної творчості у межах Українського фестивалю у Дофіні (провінція Манітоба).

В ході проведення політики мультикультуралізму уряд Канади сприяв розвитку національних культур. Протягом 1970-х рр. федеральний уряд просував політику щодо підтримки канадських музеїв та галерей, яка сприяла підвищенню доступності цих установ для широкої громадськості. Щоб скористатися цим інноваційним підходом до збереження та розвитку спадщини, Український музей Канади закріпив своє програмне пцанування та застосував фінансову допомогу для низки проектів. За рахунок фінансування проектів Національних музеїв було залучено додатковий персонал для проведення етнографічних досліджень. Крім того, було здійснено підготовку слайдів, тексту, фотографій та артефактів для пересувної виставки "Українці в Канаді: İх прекрасна мрія". Також в музеї бумо започатковано освітні програми, на яких було представлено інформацію про історію, символізм та принципи дизайну українського народного мистецтва, а також майстерк^аси, учасники яких здобували навички в техніці різних мистецтв, таких як вишивка, писанкарство, гончарство та різьба по дереву.

6 серпня 1975 р. діяльність музею було юридично закріплено в патентному документі під печаткою Міністерства споживачів та кор.поративних справ. Віднині Український музей Канади є офіційно зареєстрованою незалежною та окремою юридичною особою, що визначено законодавством. Він керується Радою директорів та головою, який є його виконавчим директором. Музей є Федерально об'єднаною корпорацією, яка не має прибутку та власника. Міністр споживчих та корпоративних справ, в силу повноважень, наділених ним Законом про корпорації Канади, $є$ заявником та особою, яка надалі може стати чценом створеної корпорації $[11$, c. 1$]$.

3 плином часу потреба у власній будівлі для Українського музею Канади тільки зростала. Однак, історичні події та економічні негаразди другої чверті XX ст. затягували процес збору коштів. У другій половині $\mathrm{XX}$ ст. за підтримки уряду Канади, який впроваджував нову соціальнокультурну політику, мрія багатьох діячів, чиенів жіночої асоціації та Інституту ім. П. Могили стала справджуватися. На 40-му з їзді Української асоціації жінок Канади, що відбулась в Торонто в 1967 р. було прийнято рішення про створення фонду з метою залучення коштів на будівництво окремої музейної будівлі та досягнення цілей з розширення колекцій та програм штаб-квартири музею в Саскатуні та його філій в Едмонтоні, Вінніпезі, Торонто та Ванкувері [15, с. 1008]. Крім того, було 
подано заявку по допомогу до Асоціації музеїв Канади. Видіменню коштів також сприяла діяльність політичного діяча - Майка Бойчука, який тоді виконував обов'язки голови канадського Комітету з фінансів та будівництва. У 1977 р. бумо затверджено проект будівлі музею, яка за зовнішнім виглядом мала б нагадувати український котедж, на першому поверсі якого мали б експонуватись різні тематичні проекти та проходити конференції, а на другому знаходитись постійна колекція, яка уособлювала б історію життя українців в Канаді. Нову будівмю музею було завершено в 1979 р. і офіційно відкрито 24 травня 1980 р.

Станом на початок XXI ст. колекція Українського музею Канади налічує більше 30 тис. артефактів. Досліджуючи наративні джерела, було з'ясовано, що колекції музею мають етнографічний, історичний та мистецький характер. Кожен з артефактів має надзвичайну національнокультурну цінність та є не тільки джерелом історії українців Канади, а взагалі історії української кумьтури. Отже, нами було типологізовано колекції музею у такі групи, як:

1.Вишивка - традиційний український одяг та його емементи, прикрашені візерунками 3 різних регіонів України від Закарпаття до Слобожанщини;

2. Ткацтво - рукотворні, майстерно оформлені кимими та ткані рушники;

3. Писанкарство - колекції Великодніх писанок, прикрашених геометричними, рослинними і тваринними візерунками з регіональними технологіями виконання;

4. Гончарство - вміщує колекції утилітарної та орнаментальної кераміки;

5. Різьба по дереву - вироби 3 дерева, прикрашені художньою різьбою, інкрустовані перламутром, намистом, елементами з кістки або металу;

\section{6. Твори живопису - полотна видатних українсько-канадських художників;}

7. Українське господарство - автентична модемь хати українського піонера, домашнє начиння та сільськогосподарське приладдя;

8. Обрядовий хліб - зразки урочистого короваю, святкового калача, різдвяного книша та весільного дивня, прикрашені зеленню або квітами;

9. Церковні артефакти - ікони, хрести, кадима, текстильні вироби та книги;

10.Фоно-, відео-, та писемні архіви - артефакти, які не мають аналогів.

Таким чином, Український музей Канади став надійним форпостом української національно-культурної ідеї. Безперечно у витоків першої української музейної установи Канади стояли талановиті українці патріоти рідної землі, члени Української асоціації жінок Канади, студенти Іституту св. Петра Могили, громадські діячі та прості громадяни, які допомагали у створенні неповторної комекції. Від першої виставки проведеної в 1929 р. до офіційного заснування музею у 1936 р., від 
церемонії відкриття першої галереї у 1941 р. до часу, коли будівля музею відкрила свої бронзові двері у 1980 р., Український музей Канади залишався головним зберігачем визначних шедеврів народної творчості, представлених вишивкою, ткацтвом, писанкарством, живописом, гончарством, різьбярством. Крім того, в музеї знаходяться унікальні експонати такі, як ткана карта України з регіональними візерунками, мініатюрна модель української хати, змайстрована П. Сваричем, гончарні вироби П. Рупчана, художні твори В. Курилика. При Українському музеї Канади працює відділ народних ремесел, віддіц етнографічних та наукових досліджень, бібліотека, проводяться освітні майстер-класи, вистави та концерти. 31948 р. музей практикує пересувні виставки, які знайомлять 3 українською культурою все населення Канади. Окрім головного музею в м. Саскатун працюють провінційні осередки в Едмонтоні, Вінніпезі, Торонто та Ванкувері. Станом на початок XXI ст. музей налічує понад 30 тис. експонатів, з них колекції текстильних виробів $\epsilon$ найкращими серед представцених за межами етнічної території. Отже, діяльність Українського музею Канади вражає своїм етнографічним, мистецьким та науковим спрямуванням та є визначним центром української культури у світі.

\section{Джерема та мітература:}

1. ВАасюк Г. М., Зосимович О. Ю., Хададова М. В. Музеєзнавство та архівна справа : навч.-метод. посіб. - Житомир : ЖДПУ ім. Івана Франка, 2006. - 75 с.

2. Войценко О. П. Аітопис украӥнського життя в Канаді. Доба росту й диференціяції : 1930-1939 рр. / О. П. Войценко. - Вінніпег: Тризуб, 1969. - Т. 4. $475 \mathrm{c}$.

3. Драган Р. Музейна збірка Союзу Українок Канади / Р. Драган. // Камєндар Українського Голосу на 1942 р. - Вінніпег: Українська Видавнича Спілка Канади, 1942. - C. $146-148$.

4. Марунчак М. Г. Історія українців Канади / М. Г. Марунчак. - Вінніпег: УВАН в Канаді, 1991. - Т. 2. -512 с.

5. Марунчак М. Г. Студії історії українців Канади. Розвідки та документи до міжвоєнноі доби / М. Г. Марунчак. - Вінніпег: Trident Press, 1980. - Т. 5. 215 c.

6. Прокоп Д. Українці в Західній Канаді: До історії їхнього поселення та поступу Едмонтон-Вінніпег: Тризуб, 1987. - 548 с.

7. Стельмащук А. Сиово у День 50-ліття чиенства // Промінь. - Ч. 6. - Вінніпег: Союз Українок Канади, 1981. - С. 9-10.

8. Стечишин С. Т. Рання історія українського музею Канади / С. Т. Стечишин // Український голос. - Вінніпег, 1980. - Вип. 4. - С. 8.

9. Табачник Д. В., Попов Г. Д. Українці зарубіжжя та України: Довідник. - К.: Знання, 2007. - 399 с.

10. Luciuk L. Y. Canada's ukrainians negotiating an identity / L. Y. Luciuk, S. Hryniuk. - Toronto: University of Toronto Press, 1991. - 567 p.

11. Museum of Ukrainian Arts and Culture of the Ukrainian Women's Association of Canada. (1975). - Canadian Patent № 286. Ottawa, ACT: IP Canada. 12. Nokony V. A. The Ukrainian Museum of Canada// The Ukrainians in Canada, 1891-1991. National Museums of Canada. Material History Bulletin / Ed. R. B. Klymasz. Vol. 29. - Ottawa: Published by the Canadian Museum Civilization and the National Museum Science and Technology, 1989. - PP. 106-107. 
13. Nokony V. A. Ukrainian Pioneer Women. - Saskatoon: Ukrainian Museum of Canada, 1991. - 14 p.

14. Ostryzniuk N. Savella Stechishin : A Case Study of Ukrainian-Canadian Women Activism in Saskatchewan, 1920-1945 / N. Ostryzniuk. - Regina: University of Regina, 1997. - $181 \mathrm{p}$.

15. Tkachuk M. The Ukrainian Museum of Canada of the Ukrainian Women's Association of Canada. Historicai Highlights - 1927-1977 // Півстоліття на громадській ниві: Нарис історії Союзу українок Канади, 1926-1976 / за ред. Н. С. Когуської. - Едмонтон-Вінніпег: Союз Українок Канади, 1986. - С. 973-1018.

16. Ukrainian Canadiana / Ed. N. Faryna, Art director P. M. Sembaliuk. Edmonton: Ukrainian Women`s Association of Canada, 1976. - 96 p.

17. Ukrainians in North America. A Biographical Directory of Noteworthy Men and Women of Ukrainian Origin in the United States and Canada / Ed. D. M. Shtohryn. - Champaign : Association for the Advancement of Ukrainian Studies, 1975. - 424 p.

\section{Referens:}

1. Vlasyuk, H. M., Zosymovych, O. Yu. \& Khadadova, M. V. (2006). Muzeyeznavstvo ta arkhivna sprava : navchal'no-metodychnyy posibnyk. Zhytomyr: ZhDPU im. Ivana Franka. [in Ukrainian]

2. Voytsenko, O. P. (1969). Litopys ukrayins'koho zhyttya $v$ Kanadi. Doba rostu $y$ dyferentsiyatsiyi : 1930-1939 rr. (Vol. 4). Winnipeg: Tryzub. [in Canadian].

3. Dragan, R. (1942). Muzeyna zbirka Soyuzu Ukrayinok Kanady. Kalyendar Ukrayins'koho Holosu na 1942 rik - Calendar of Ukrainian Voice for 1942. Winnipeg: Ukrayins'ka Vydavnycha Spilka Kanady, 146-148. [in Canadian].

4. Marunchak, M. H. (1991). Istoriya ukrayintsiv Kanady. (Vol. 2). Winnipeg: UVAN v Kanadi. [in Canadian].

5. Marunchak, M. H. (1980). Studiyi istoriyi ukrayintsiv Kanady. Rozvidky ta dokumenty do mizhvoyennoi doby. (Vol. 5). Winnipeg: Trident Press. [in Canadian].

6. Prokop, D. (1987). Ukrayintsi $v$ Zakhidniy Kanadi: Do istoriyi yikhn'oho poselennya ta postupu. Edmonton-Winnipeg: Tryzub. [in Canadian].

7. Stel'mashchuk, A. (1981). Slovo u Den' 50-littya chlenstva. Promin' - The Ray, Winnipeg: Soyuz Ukrayinok Kanady, 6, 9-10. [in Canadian].

8. Stechyshyn, S. T. (1980). Rannya istoriya ukrayins'koho muzeyu Kanady. Ukrayins'kyy holos - Ukrainian Voice. Winnipeg, 4, 8. [inCanadian].

9. Tabachnyk, D. V., \& Popov, H. D. (2007). Ukrayintsi zarubizhzhya ta Ukrayiny: Dovidnyk. Kyiv: Znannya. [in Ukrainian].

10. Luciuk, L. Y., \& Hryniuk, S. (1991). Canada's ukrainians negotiating an identity. Toronto: University of Toronto Press. [in Canadian].

11. Museum of Ukrainian Arts and Culture of the Ukrainian Women's Association of Canada. (1975). Canadian Patent № 286. Ottawa, ACT: IP Canada. [in Canadian].

12. Nokony, V. A. (1989). The Ukrainian Museum of Canada. In R. B. Klymasz (Ed.), The Ukrainians in Canada, 1891-1991. National Museums of Canada. Material History Bulletin (Vol. 29, pp. 106-107). Ottawa: Published by the Canadian Museum Civilization and the National Museum Science and Technology. [in Canadian].

13. Nokony, V. A. (1991). Ukrainian Pioneer Women. Saskatoon: Ukrainian Museum of Canada. [in Canadian]. 
14. Ostryzniuk, N. (1997). Savella Stechishin: A Case Study of Ukrainian-Canadian Women Activism in Saskatchewan, 1920-1945. Regina: University of Regina. [in Canadian].

15. Tkachuk, M. (1986). The Ukrainian Museum of Canada of the Ukrainian Women's Association of Canada. Historicai Highlights - 1927-1977. In N. S. Kohus'ka (Ed.), Pivstolittya na hromads'kiy nyvi: Narys istoriyi Soyuzu ukrayinok Kanady, 1926-1976. (pp. 973-1018). Edmonton-Winnipeg: Soyuz Ukrayinok Kanady. [in Canadian].

16. Faryna, N. (Ed.). (1976). Ukrainian Canadiana. Edmonton: Ukrainian Women`s Association of Canada. [in Canadian].

17. Shtohryn, D. M. (Ed.). (1975). Ukrainians in North America. A Biographical Directory of Noteworthy Men and Women of Ukrainian Origin in the United States and Canada. Champaign: Association for the Advancement of Ukrainian Studies. [in American].

\author{
Анатолий Бодруг \\ ORCID: https://orcid.org/0000-0001-6718-4957 \\ Аспирант кафедры истории Украины, \\ Одесский национальный университет \\ имени И. И. Мечникова \\ УА. Дворянская, 2, Одесса, 65082, Украина \\ metall.feniks@yandex.ua
}

\title{
Деятельность Украинского музея Канады по сохранению национального наследия (вторая четверть $X X-$ начало $X X I$ вв.)
}

Цель данного научного исследования заключается в рассмотрении деятельности Украинского музея Канады и обосновании его вклада в проиесс сохранения культурного наследия украинской диаспоры. Благодаря памятникоохранной деятельности исследуемого музея бъли не только сохранены, а и приумножены ростки украинской культуры, несмотря на эпоху военного лихолетья и в положении практической оторванности от этнической территории. Для достижения указанной иели было привлечено необходимое количество источников и историографической литературы, которые касались различных аспектов затронутой проблемы. Автором бъли применены следуюшие обшеисторические научные методы исследования, как историко-генетический, историко-сравнительный и историкотипологический. В рамках данной научной статьи были рассмотрены генезис музейного учреждения, типологизированы имеюшиеся коллекиии $и$ проанализирована их иенность. Отдельное внимание посвяшено исследованию роли учредителей и меиенатов в развитии Украинского музея Канады. Впервые предпринята попытка обобшения различных аспектов проблемы.

ключевые слова: украинская диаспора Канады, Украинский музей Канады, украинское искусство, Украинская ассоииаиия женшин Канады, музееведение.

Отримано: 31.10.2019p. 